\title{
CLASSIFICATION OF REPRODUCTION TYPES OF HUMAN CAPITAL IN THE CONTEXT OF STATE REGULATION
}

\author{
Nadiia Benko \\ Department of Finance, Accounting, and Fundamental Economic Sciences \\ National Academy of Management \\ 15 Ushinskogo str., Kyiv, Ukraine, 03151 \\ nadiya.benko@gmail.com
}

Abstract

The article examines the essence of the reproduction of human capital process, reveals its main stages (phases) -formation, distribution, exchange and consumption. The specificity of each stage of reproduction of human capital is considered, which makes it possible to realize the need for purposeful investment in a person and study the problems of state regulation at each of the stages.

The article also shows that the reproduction of human capital occurs at the individual, corporate and national levels.

Based on the study of the literature, a classification of the types of reproduction of human capital has been developed. This allows investing in human capital in order to create high quality human capital for the country. The classification of the types of reproduction of human capital is considered according to such characteristics as: the scale of reproduction, the nature of labor resources, the direction of reproduction, the innovativeness of the reproduction process, the completeness of the reproduction process, stages (phases, stages) of the reproduction process and structural components. The expanded reproduction of human capital is disclosed in detail, on which the state regulation of the economy of the most developed countries of the world is focused. The article notes the importance of the reproduction of human capital in providing an innovative "breakthrough" in engineering, technology, organization of production and management.

The influence of the process of reproduction of human capital on the development of the country's economy has been investigated. The necessity of enhancing the activities of the state to create conditions for the effective formation, distribution, exchange and use of human capital has been substantiated.

The role of the state in the formation (accumulation) of human capital through public goods for a person and through the establishment of norms and rules created in society and contributing to the development of this society is presented.

Keywords: human capital, reproduction of human capital, formation, exchange, distribution, use.

DOI: $10.21303 / 2504-5571.2021 .001715$

\section{Introduction}

The increased attention to the problems of theory and practice of reproduction of human capital is due to the fact that human capital has become a determining factor in the growth of the economy, its transition to an innovative path of development. High-quality human capital helps to increase labor productivity, which leads to an increase in national wealth and an improvement in living standards.

In this regard, there is a need to create favorable conditions for the reproduction of human capital, improving its quality and constant growth of returns in the process of its use.

The question of classifying the types of reproduction of human capital is of great theoretical and applied importance, since the question of the priority of investing in human capital at the state level directly depends on the identification of the type of reproduction of human capital.

Thus, the study of the process of reproduction of human capital and the classification of its types is of particular relevance at the present stage of the country's development.

Scientific works of foreign and domestic scientists, the subject of research of which is the reproduction of human capital, contain an examination of the essence and components of the process of reproduction of human capital.

The works of foreign scientists [1,2] are devoted to the consideration of the reproduction of human capital and investments in education, their experience in these matters are applicable in Ukraine. 
Own observations and special studies have shown that the authors [3, 4] ambiguously defined the stages (stages) of the reproduction of human capital process, which requires further clarification.

The works of A. Nosik are devoted to the classification of types of human capital. [3] and O. Shevchuk [5] However, the authors do not consider the classification features from the perspective of investment and state regulation of the reproduction of human capital, which requires further study.

Aim of the article. Classification of reproduction types of human capital to determine the priority areas of investment in human capital at the state level.

\section{Methods}

This research was carried out on the basis of general scientific and special methods based on the dialectical method of cognition and the objective laws of economic development. The main general scientific research methods that were used include: the method of system analysis and abstraction - to study the essence of concepts such as "reproduction of human capital", "stages of reproduction of human capital", methods of grouping and systematization - when classifying types of human capital, abstract logical - when forming conclusions.

\section{Research results}

The globalization of the world economy, efforts to enter Ukraine into various world organizations and its desire to become a developed country with a competitive economy, determines the need for competent, highly qualified and highly educated specialists, that is, people with high-quality human capital.

Many specialists in human resource management pay attention to features specific to human capital: aging of knowledge, the ratio of explicit and implicit knowledge in the structure of human intellectual resources. The knowledge aging process does not mean the loss of knowledge associated with the biophysical aging of the employee, but a phenomenon similar to the obsolescence of equipment.

The deterioration process of human capital has two sides: there is a natural displacement from the active memory of an individual of a part of knowledge that is not used and the obsolescence of a number of information and provisions under the onslaught of the latest achievements of science and technology.

In modern economic conditions in society, there is an interest in the reproduction of human capital. What is connected with its movement in time, during which it is formed, accumulated, distributed, exchanged, used, lost and restored again, and its stock grows in quantitative, qualitative and cost dimensions [3].

The study of the essence, types of human capital and their classification are devoted to the works of scientists $[3,6]$, however, the opinions of the authors differ in the study of the stages (phases) of reproduction of human capital, this is due to the ambiguity of these stages and their content.

A. Zakharova considers the stages of reproduction of human capital from the perspective of an employee, highlighting five stages of his/her life cycle: labor adaptation, professional growth, accumulation of professional experience, professional implementation and reduction of professional implementation [6]. The main criterion for referring to a certain stage, in her opinion, is the employee's attitude to professional development, but this approach is subjective.

O. Nosik examines the reproduction of human capital in a narrow and broad sense. Reproduction of individual human capital in the narrow sense - an investment cycle, is carried out within the life time of a person and "covers the period of a person's life time, during which, on the basis of investments, they are formed (restored), developed (accumulated), used and restored at a new level of his/her knowledge, skills". In a broad sense, the reproduction of human capital is a cyclical and multilevel field $[3,7]$.

The process of formation of human capital is carried out over a long period before the start of labor activity, and at the stage of development, knowledge, experience, and health are restored and replenished. 
The reproduction of individual human capital consists in the continuous restoration and maintenance of the mental, physical, professional forces and abilities of a person, that is, including a reduced number of stages, the already formed or accumulated capital is restored.

Based on this, we support the opinion of A. Shevchuk that the reproduction of human capital is a continuous process of restoring its properties, which includes four stages: formation (production, accumulation), distribution, exchange and consumption (use) [7].

It should be noted that these stages have their own specifics. At the stage of production (formation), human capital is formed, there is a process of obtaining education, strengthening the health of individuals, as well as the formation and development of their socio-cultural level. At this stage, the accumulation of certain knowledge directly occurs, which later a person uses in the production process. A. Shevchuk emphasizes that "the production of human capital is an end in itself of the reproduction process. This is an increase in the volume or quality of human capital, improvement of its structure and its active development" [5].

The stage of distribution includes the search for the first place of work by graduates of universities and secondary specialized educational institutions, as well as the participation of the state and potential employers in this process, that is, human capital is included in social and labor relations. At this stage, a person begins to use the accumulated knowledge in certain areas and sectors of the economy.

At the exchange stage, a certain intellectual base of any business entity is exchanged for remuneration for its activities (wages). The stage of exchange is also characterized by an objective and inevitable process caused by the reasons for the territorial mobility of labor resources, the need for people to build their careers, which is associated with the processes of flow of labor resources between individual enterprises and organizations, as well as industries, sectors of the economy, regions and states.

At the consumption stage, there is a useful use of the accumulated human capital in the process of production or other socio-economic activity, and the basis for its further improvement is formed. The state, one of the subjects of consumption, receives tax revenues, and society as a whole receives some public goods as a result of the beneficial use of human capital. The main subject of human capital consumption at this stage is the direct employer.

All considered stages of the reproduction process require significant investments, households, firms (enterprises), the state. Both the reproduction process itself and its individual stages must be regulated by the state. It must provide conditions for the creation of new jobs, adequate wages, the preservation and harmonious development of a person through effective legislation and investment mechanisms. The state concept of education and state policy in this area are of great importance.

A detailed study of the stages of reproduction of human capital makes it possible to realize the need for purposeful investment in a person and study the problems of state regulation at each of the above stages.

To understand the volumes and directions of state investment in human capital, it is necessary to consider the types of reproduction of human capital and their classification.

The issues of classification of types of human capital are of great theoretical and applied importance - the correctness and efficiency of the choice of specific methods of its improvement at the state level directly depend on the exact identification of the type of reproduction of human capital.

Based on the study of literary $[1,4,5,8]$ sources, the authors made an attempt to classify the types of reproduction of human capital (Table 1).

The differentiation of the types of the reproductive process into simple, narrowed and extended reproduction is traditional for any directions of reproduction. The reproduction of human capital is simple when, within the framework of this process, human capital is restored approximately at the same scale.

At the same time, human capital does not acquire any fundamentally new quality; the state of health is maintained at the current level, without significant improvement; the level of a person does not improve qualitatively; there is no mastery of new methods of cognition, etc. 
Table 1

Classification of types of reproduction of human capital

Classification attribute

Reproduction scale

The nature of the workforce

Reproduction direction

Innovativeness of the reproduction process

Completeness of the reproduction process

Stage (phase, stage) of the reproductive process

Structural constituents
Types of reproduction of human capital

$$
\begin{aligned}
& \text { - extended; } \\
& \text { - simple; } \\
& \text { - narrowed }
\end{aligned}
$$

- reproduction of human capital employed in certain sectors of the national economy;

- reproduction of human capital of officially registered unemployed; - reproduction of those employed in the "gray" labor market

- reproduction by extensive growth;

- reproduction by intensive growth

- reproduction, which causes only quantitative changes in the socio-economic sphere; - reproduction, which causes qualitative changes;

- reproduction, is the basis of innovative "Breakthrough" in engineering, technology, organization of production, etc.

- reproduction, sequentially includes all four stages;

- reproduction, including a reduced number of stages (for example, carried out according to the "production-consumption of human capital" scheme), there can be continuous restoration and maintenance of mental, physical, professional forces and abilities of a person

- reproduction at the formation stage;

- reproduction at the distribution stage;

- reproduction at the exchange stage;

- reproduction at the use stage

- reproduction of knowledge (secondary education, vocational training, retraining) - reproduction of skills, abilities (employment); - health reproduction (health care)

- in the reproduction of culture and other components

Source: developed by the author on the basis of [1, 4, 5, 8].

Narrowed reproduction of human capital occurs both for natural reasons, such as age or a difficult life situation in which a particular person has found itself, and as a result, for example, of insufficient state funding for education and health care or the use of outdated methods by the latter, respectively, training and treatment.

It is possible to talk about expanded reproduction when, within the framework of this process, all or at least some elements of an individual's human capital acquire fundamentally new, improved properties. At the state level, the expanded reproduction of human capital is manifested in the emergence of new professions, new forms of employment (virtual employment is relevant), in a significant improvement in the health of the population, an increase in life expectancy, etc.

As noted by S. Tiutiunnikov and I. Shpak, the expanded reproduction of human capital is not reduced to a simple increase in the population, but includes the development of human potential, its qualities and properties, which are involved in social production, making it more efficient, and labor - more productive [8].

It is on the expanded reproduction of human capital that state regulation of the economy of the most developed countries of the world is focused.

Depending on the classification criterion "nature of labor resources", the reproduction of their various categories is possible. In addition to the reproduction of the human capital of the employed population, it is possible to reproduce the knowledge, skills and abilities of the officially registered unemployed. This kind of reproduction is usually carried out at the expense of the state within the framework of personnel retraining programs. Finally, the least effective from the socio-economic point of view is the reproduction of human capital employed in the so-called "gray" (unregistered) labor market [1].

Based on the previous classification criterion, it can be noted that the reproduction of human capital can occur in two directions, since economic growth occurs only under conditions of ex- 
panded production. Reproduction of human capital occurs: through extensive growth and through intensive growth [5].

An essential classification feature that directly reflects the quality of the results of the use of human capital is the "innovativeness of the reproduction process". One of the properties of human capital is the ability to generate innovation. However, not every reproduction of human capital is capable of providing an innovative "breakthrough" in engineering, technology, organization of production and management. Adequate education is able to provide this breakthrough, which is the main indicator of the state and development of human capital.

However, it is necessary to understand that the problems associated with the reduction of jobs and, accordingly, employment, can be the consequences of robotization and artificial intelligence, which in turn must be solved.

Studies by the Global Institute of the international consulting company Mc Kinsey believe that automation technologies, including artificial intelligence and robotics, will not be aimed at replacing workers at the present stage: robots will act next to humans, expanding their capabilities and increasing labor productivity $[9,10]$.

It is also advisable to classify the process of reproduction of human capital depending on the completeness of the implementation of the reproduction process. So, in the process of the first cycle of the formation of an individual, almost every person goes through all the stages of reproduction sequentially: production (acquisition) of knowledge, distribution, exchange and consumption. At the same time, if a person receives additional knowledge (advanced training), only two stages of the reproduction process take place: the production of new properties of human capital and its consumption within the framework of labor activity in the same company [1].

Human capital in the stage of formation is human capital, which was obtained through systematic education, due to which a person develops and transforms it into a professional participant in social and economic activity, capable of being actively involved in modern social production. Human capital at the stage of use is human capital that was accumulated in the labor process, that is, vocational training, when the acquired knowledge and professional skills are implemented, as well as improvement through direct retraining in social production [5].

At the macroeconomic level, the reproduction of human capital is carried out, which includes investments in such areas of activity as education (science), vocational training and retraining, vocational guidance and employment, health improvement, social and labor mobility, and the like. Therefore, it makes sense to classify the reproduction of human capital by individual structural components of human capital.

The state plays an important role in the reproduction of human capital. It can be presented in two ways: on the one hand, these are various programs and support for a person through involvement in development through public goods, and on the other hand, it is an institutional environment, a set of norms and rules created in society and contributing to the development of this society.

In the annual reports of the international organization "United Nations Development Program" (UNDP) "Report on Human Development", it is proposed to proceed from the fact that the state ensures not so much equality of consumption as equality of opportunities, primarily in the field of education, health care, security, political and civil right [11].

At the macro level, the determination of the need for human capital forms the tasks of the state, which in turn depends on the volume and types of investments in human capital at the corresponding stages of reproduction. Under such conditions, it is important to manage costs at the stages and cycles of reproduction of human capital.

\section{Conclusions}

Based on the study of the stages of reproduction of human capital, it can be noted that the reproduction of human capital is a continuous process of restoring its properties, which includes four stages: formation (production, accumulation), distribution, exchange and consumption (use).

The developed classification of the types of reproduction of human capital makes it possible to analyze, evaluate and invest in human capital at different levels (individual, corporate, state), 
which will allow the most efficient way to coordinate the efforts of households, enterprises and the state to create high-quality human capital.

\section{Acknowledgement}

I am grateful to Doctor of Science, Professor Irina Shtuler for assistance in researching the issues of reproduction of human capital and its regulation at the state level.

\section{References}

[1] Galiev, E. Sh. (2009). Vosproizvodstvo chelovecheskogo kapitala v usloviiakh tsiklichnosti rossiiskoi ekonomiki. Kazan, 23. Available at: https://static.freereferats.ru/_avtoreferats/01004567637.pdf Last accessed: 10.02.21

[2] Matthew, C., Weil, D. N. (20180. The Effect of Increasing Human Capital Investment on Economic Growth and Poverty: A Simulation Exercise. Policy Research Working Paper 8590. Washington: World Bank. doi: http://doi.org/10.1596/ 1813-9450-8590

[3] Nosyk, A. N. (2016). Liudskyi kapital innovatsiinoho rozvytku: ekonomichni osnovy vidtvorennia. Kharkiv: Yzd-vo, 490.

[4] Shakhno, A. Yu. (2019). Liudskyi kapital v umovakh hlobalizatsii: otsiniuvannia, rozvytok ta derzhavne rehuliuvannia. Kryvyi Rih: Cherniavskyi D. A., 360.

[5] Shevchuk, O. A. (2009). Vydy vidtvorennia liudskoho kapitalu. Ekonomichnyi visnyk NTUU «KPI», 6, 37-42.

[6] Zakharova, A. V. (2010). Upravlinnia investuvanniam u liudskyi kapital:metodolohiia, otsinka, planuvannia. Donetsk: «DVNZ DonNTU», 378 .

[7] Nosyk, E. N. (2014). The reproduction of human capital in the aspect of the cyclical approach. French Journal of Science and Education, 2, 375-381.

[8] Tiutiunnykova, S. V., Shpak, Y. A. (2020). Rozshyrene vidtvorennia liudskoho kapitalu yak faktor staloho rozvytku. Biznes Inform, 4, 471-478

[9] TSifrovaia Rossiia: novaia realnost (2017) Available at: http://www.tadviser.ru/images/c/c2/Digital-Russia-report.pdf Last accessed: 03.03.21

[10] Forecast: Enterprise IT Spending by Vertical Industry Market, Worldwide, 2015-2021, 1Q17 Update (2017). Gartner. Available at: https://www.gartner.com/doc/3696317/forecast-enterprise-itspending-vertical

[11] Human development Report 2019. Available at: http:/hdr.undp.org/sites/default/files/hdr2019.pdf

How to cite. Benko, N. (2021). Classification of reproduction types of human capital in the context of state regulation. EUREKA: Social and Humanities, 2, 11-16. doi: http://doi.org/10.21303/2504-5571.2021.001715 